\title{
A retrospective study of ectopic pregnancies in a tertiary care hospital
}

\section{Anuradha Murugesan*, Karthiga Prabhu, Muthulakshmi M.}

\author{
Department of Obstetrics and Gynaecology, SRM Medical College, Kanchipuram, Tamilnadu, India
}

Received: 06 July 2016

Revised: 10 July 2016

Accepted: 14 July 2016

\section{*Correspondence:}

Dr. Anuradha Murugesan,

E-mail: anuthanigai@yahoo.com

Copyright: (C) the author(s), publisher and licensee Medip Academy. This is an open-access article distributed under the terms of the Creative Commons Attribution Non-Commercial License, which permits unrestricted non-commercial use, distribution, and reproduction in any medium, provided the original work is properly cited.

\section{ABSTRACT}

Background: Ectopic pregnancy is a common life threatening emergency in first trimester of pregnancy and it leads to serious maternal morbidity and also can cause mortality. The aim was to study the incidence, clinical presentation, risk factors and the management of patients with ectopic pregnancies admitted in our hospital over three year period. Methods: The present study involves a retrospective analysis of ectopic pregnancies admitted in SRM Medical college hospital for three years from 2012 to 2015.

Results: The incidence of ectopic pregnancy in the present study is $1.77 \%$. About $79 \%$ of the women were in the age group of 21-30 years. About $79 \%$ of patients in present study belonged to low socioeconomic status. In the study ectopic pregnancies were more common among multigravida (78\%). $73 \%$ of patients had identifiable risk factors of which tubal surgeries were more common (31.15\%). Ultrasound was diagnostic of ectopic pregnancy in $85 \%$ of patients. $97.26 \%$ were tubal ectopic pregnancies and $2.74 \%$ were ovarian ectopic pregnancies. Among tubal pregnancies majority of cases were ampullary pregnancies $(62 \%)$. All patients in the study underwent surgical management.

Conclusions: Ectopic pregnancy is still a major challenge in gynaecological practice. Early diagnosis and early referral is the key to successful management. It is better to over diagnose an ectopic pregnancy especially in a rural setup. Most cases present late, making tubal conservation treatment inapplicable. The impact on future fertility can be improved by focusing on primary prevention and early diagnosis before rupture so that conservation treatment can be done.

Keywords: Ectopic pregnancy, Salpingectomy, Tubal, Ampullary, Morbidity

\section{INTRODUCTION}

Ectopic pregnancy is a common life threatening emergency in first trimester of pregnancy and it leads to serious maternal morbidity and also can cause mortality. It not only leads to pregnancy wastage but also results in recurrence of ectopic pregnancy and reduction in fertility.

The rising incidence of ectopic pregnancy in the past few years is due to a number of risk factors which include pelvic inflammatory disease, infertility, intrauterine contraceptive device, tubal surgeries, assisted reproductive techniques and availability of better diagnostic techniques.

The early diagnosis and treatment of this condition over the past two decades has allowed a definitive medical management of unruptured ectopic pregnancies even before there were clinical symptoms in these high risk women so that tubal conservation is possible.

The present study analyses the incidence, clinical presentation, risk factors, diagnosis, management and maternal morbidity of ectopic gestation. 


\section{METHODS}

This was a retrospective study of ectopic pregnancies managed at SRM medical college hospital for three years from 2012 to 2015. The case records of the patients with ectopic pregnancy were traced from medical records department and theatre registers. All the relevant information were entered in a proforma prepared by the author which in turn analysed after entering in the excel sheets using descriptive analysis

\section{RESULTS}

The incidence of ectopic pregnancy in the present study is $1.77 \%$. About $79 \%$ of the women were in the age group of 21-30 years. About $79 \%$ of patients in the study belonged to low socioeconomic status. Ectopic pregnancies were more common among multigravida (78\%) (Table 1). Maximum number of patients were in gestational age of 6 to 8 weeks $(65.75 \%)$.

Table 1: Demography.

\begin{tabular}{|lll|}
\hline Parameters & No. of cases & Percentage \\
\hline Age & 1 & 1.37 \\
\hline$<20$ & 58 & 79.45 \\
\hline $21-30$ & 14 & 19.18 \\
\hline $30-40$ & & \\
\hline Parity & 16 & 21.92 \\
\hline Primigravida & 57 & 78.08 \\
\hline Multigravida & & \\
\hline Socioeconomic status & 15 & 20.55 \\
\hline $\begin{array}{l}\text { High socioeconomic } \\
\text { status }\end{array}$ & 58 & 79.45 \\
\hline $\begin{array}{l}\text { Low socioeconomic } \\
\text { status }\end{array}$ & & \\
\hline
\end{tabular}

Table 2: Risk factors.

\begin{tabular}{|lll|}
\hline Risk factors & No. of cases & Percentage \\
\hline Previous ectopic & 4 & 5.48 \\
\hline Infertility & 8 & 10.96 \\
\hline Tubal surgeries & 23 & 31.51 \\
\hline Sterilisation & 21 & 28.76 \\
\hline Recanalisation & 2 & 2.74 \\
\hline $\begin{array}{l}\text { Pelvic inflammatory } \\
\text { diseases }\end{array}$ & 7 & 9.59 \\
\hline $\begin{array}{l}\text { Intrauterine } \\
\text { contraceptive device }\end{array}$ & 1 & 1.37 \\
\hline Previous abortion & 14 & 19.17 \\
\hline Bicornuate uterus & 1 & 1.37 \\
\hline $\begin{array}{l}\text { Previous } \\
\text { appendicectomy }\end{array}$ & 1 & 1.37 \\
\hline No risk factors & 21 & 28.77 \\
\hline
\end{tabular}

In present study $73 \%$ of patients had identifiable risk factors of which tubal surgeries (sterilisation and tubal recanalisation) was found in $31.15 \%$ followed by previous abortion (19.17\%). $28.77 \%$ of patients had no identifiable risk factors (Table 2).

Table 3: Clinical features.

\begin{tabular}{|l|l|l|}
\hline Clinical features & No. of cases & Percentage \\
\hline Amenorrhoea & 65 & 89.1 \\
\hline Pain & 70 & 95.89 \\
\hline Bleeding per vaginum & 26 & 35.62 \\
\hline Pallor & 37 & 50.68 \\
\hline Tachycardia & 22 & 30.14 \\
\hline Hypotension & 10 & 13.7 \\
\hline Abdominal distention & 19 & 26.1 \\
\hline Abdominal tenderness & 59 & 80.82 \\
\hline $\begin{array}{l}\text { Cervical movement } \\
\text { tenderness }\end{array}$ & 41 & 45 \\
\hline Forniceal tenderness & 49 & 67.5 \\
\hline Adnexal mass & 10 & 13.7 \\
\hline
\end{tabular}

$89 \%$ of patients had amenorrhoea, $96 \%$ of patients presented with pain abdomen, $35 \%$ of patients had bleeding per vaginum. $13.7 \%$ of patients presented with features of shock. $50 \%$ of patients had anaemia due to hemoperitoneum. $26 \%$ of patients had abdominal distention. Abdominal tenderness was present $80 \%$ of the patients. Cervical movement tenderness was present in $45 \%$ and forniceal tenderness in $67.5 \%$ of patients. Adnexal mass was palpable in $13.7 \%$ (Table 3). Urinary HCG was positive in $87.6 \%$ and negative in $5.48 \%$ of patients. Ultrasound was diagnostic of ectopic pregnancy in $85 \%$ of patients.

Table 4: Operative findings.

\begin{tabular}{|lcl|}
\hline Operative findings & No. of cases & Percentage \\
\hline Site & & \\
\hline Tubal & 71 & 97.26 \\
\hline Ampullary & 44 & 61.97 \\
\hline Isthmial & 16 & 22.54 \\
\hline Fimbrial & 9 & 12.67 \\
\hline Cornual & 2 & 2.82 \\
\hline Ovarian & 2 & 2.74 \\
\hline Course of ectopic pregnancy & \\
\hline Ruptured & 45 & 61.64 \\
\hline Unruptured & 10 & 13.7 \\
\hline Tubal abortion & 18 & 24.65 \\
\hline Hemoperitoneum & & \\
\hline$<100 \mathrm{ml}$ & 11 & 15.07 \\
\hline $100-500 \mathrm{ml}$ & 25 & 34.25 \\
\hline $500 \mathrm{ml}-1000 \mathrm{ml}$ & 10 & 13.7 \\
\hline$>1000 \mathrm{ml}$ & 17 & 23.28 \\
\hline
\end{tabular}

71 cases $(97.26 \%)$ were tubal ectopic pregnancies out of which $60.56 \%$ was ruptured, $14 \%$ unruptured and $25.35 \%$ tubal abortion. 2 cases $(2.74 \%)$ were ovarian ectopic pregnancies both ruptured. Right side ectopic gestation was more common (58.9\%). Among tubal ectopic pregnancies majority of cases were ampullary 
pregnancies $(62 \%)$ followed by isthmus $(22.5 \%)$, fimbrial $(12.67 \%)$ and cornual $(2.82 \%) .23 .28 \%$ of patients had more than one litre of blood loss (Table 4).

Table 5: Surgery.

\begin{tabular}{|lll|}
\hline Surgery & No. of cases & Percentage \\
\hline $\begin{array}{l}\text { Laparoscopic } \\
\text { salpingectomy }\end{array}$ & 15 & 20.55 \\
\hline Laparotomy & & \\
\hline Salpingectomy & 44 & 60.27 \\
\hline Partial salpingectomy & 12 & 16.44 \\
\hline Partial ovariotomy & 2 & 2.7 \\
\hline
\end{tabular}

$20.55 \%$ underwent laparoscopic salpingectomy. Among laparotomy $(79.4 \%)$ salpingectomy was done in $60.27 \%$, partial salpingectomy in $16.44 \%$ and partial ovariotomy in $2.7 \%$. Two patients underwent salpingectomy due to failed methotrexate (Table 5). Blood transfusion was required in $48 \%$ of patients. $10.95 \%$ had more than 3 transfusions. Maternal morbidity was due to anaemia $(27.4 \%)$ and wound infection $(8.22 \%)$. One patient had bronchospasm as anaesthetic complication. There was no maternal mortality.

\section{DISCUSSION}

The incidence of ectopic pregnancy has increased in last 20 years. The incidence in present study was $1.77 \%$ comparable to the study done by Musa et al (1.74\%) and Prasanna B et al $(1.8 \%){ }^{2,3}$ The rising incidence of ectopic pregnancy in the past few years is due to a number of risk factors which include pelvic inflammatory disease, infertility, intrauterine contraceptive device, tubal surgeries, assisted reproductive techniques and availability of better diagnostic techniques. In present study majority of the women were in the age group of 21 to 30 years and most of them were multigravida (78\%) which is comparable to the study done by Singh et al which may be because this is the most fertile period with infrequent contraception usage. ${ }^{4}$ Majority of them belonged to low socioeconomic status. Women belonging to low socioeconomic status will have poor personal hygiene and lack of immunity, predisposing them to pelvic inflammatory diseases including tuberculosis. $67.75 \%$ were in the gestational age of 6 to 8 weeks. This may be due to more number of ampullary tubal pregnancies which usually ruptures around 8 weeks.

$73 \%$ of patients had identifiable risk factors of which tubal surgeries (sterilisation and tubal recanalisation) was found in $31.15 \%$ which is comparable to the study by Singh $\mathrm{S}$ et al and Lakshmi $\mathrm{N}$ et al. ${ }^{4,5}$ The reason of such a high incidence is probably due to the early age of tubectomy in women predisposing them to higher rate of subsequent recanalization and tubal pregnancy. ${ }^{5}$ History of previous ectopic pregnancy was found in $5.48 \%$ of patients correlating with the studies done by Samiya M et al $(5.26 \%)$ and Uzma $\mathrm{S}$ et al $(5 \%){ }^{6,7}$ There is increased risk of ectopic pregnancy with previous ectopic pregnancy because it reflects the underlying tubal pathology which is almost always bilateral. 19.17\% had previous abortion correlating with study by Rashmi A et al $(18.91 \%)^{8}$

$96 \%$ of patients presented with pain abdomen, $90 \%$ of patients had history of amenorrhoea and $35 \%$ had bleeding per vaginum which correlates with the study by Prasanna et al in which $96 \%$ of the patients had history of amenorrhea, 90\% had pain abdomen and 68\% had bleeding per vaginum. ${ }^{3}$ In present study $13.7 \%$ of patients presented with features of shock which is almost similar to the study by Panchal D et al. ${ }^{9} 50 \%$ of patients had anaemia which is correlating with the study done by Prasanna B et al. ${ }^{3} 4 \%$ of patients did not have any signs and symptoms and they were diagnosed by routine ultrasonography.

Urinary HCG was positive in $87 \%$ of patients and negative in $12.32 \%$ which is less than when compared to the study done by Rashmi A et al $(97.3 \%)$ and Prasanna et al $(96 \%))^{3,8}$ In present study $85 \%$ of patients were diagnosed by ultrasonography which is comparable to the study by Lakshmi $\mathrm{N}$ et al $(83.3 \%){ }^{5}$

Among ectopic pregnancies $97.26 \%$ were tubal and $2.74 \%$ were ovarian ectopic pregnancies. Among tubal pregnancies $60.56 \%$ were ruptured, $14 \%$ unruptured and $25.35 \%$ were tubal abortion. Majority of cases were ampullary pregnancies (62\%) followed by isthmus (22.5\%), fimbrial (12.67\%) and cornual (2.82\%).

Ectopic pregnancy can be treated by medical method or surgery depending upon clinical condition of the patient, site, size of ectopic pregnancy, HCG Levels and availability of resources. In present study only two patients underwent medical therapy because most of them did not meet the criteria for medical management and some patients who met the criteria were not willing for Methotrexate. Two patients who underwent medical management had rupture and subsequently Laparotomy with salpingectomy was done. Stovall TG et al has suggested that $3.3 \%$ of patients undergoing medical management had rupture even after meeting selection criteria. $^{10}$ All patients in present study underwent laparoscopy $(20.55 \%)$ or laparotomy $(79.45 \%)$ depending upon the clinical condition of the patient. This is because patients themselves presented late as our hospital is tertiary care centre with many referrals. There was no maternal mortality due to ectopic pregnancy because of availability of adequate infrastructure, blood transfusion facilities and supporting speciality departments like anaesthesia and intensive care.

\section{CONCLUSION}

Ectopic pregnancy is still a major challenge in gynaecological practice. Early diagnosis and early referral are the key to successful management. It is better 
to over diagnose an ectopic pregnancy especially in a rural setup. Most cases present late, making tubal conservation treatment inapplicable. The impact on future fertility can be improved by focussing on primary prevention and early diagnosis before rupture so that conservation treatment can be done.

Funding: No funding sources

Conflict of interest: None declared

Ethical approval: Not required

\section{REFERENCES}

1. Udigwe GO, Umeononihu OS, Mbachu II. Ectopic pregnancy: a 5 year review of cases at Nnamdi Azikiwe university teaching hospital (NAUTH) Nnewi. Niger Med J. 2010;51:160-3

2. Musa J, Daru PH, Mutihir JT, Ujah IA. Ectopic pregnancy in Jos Northern Nigeria: Prevalence and impact on subsequent fertility. Niger J Med, 2009; 18:35-8.

3. Prasanna B, Jhansi CB, Swathi K, Shaik MV. A study on risk factors and clinical presentation of ectopic pregnancy in women attending a tertiary care centre. Int Archives Int Med. 2016;3(1):90-6.
4. Singh S, Pukale RS. Clinical study of ectopic pregnancy in a rural setup: a two year survey. Natl $\mathbf{J}$ Med Res. 2014;4(1):37-9.

5. Lakshmi N, Nirmala P, Adlin R. A retrospective analysis of ectopic pregnancy in a tertiary care centre in South Kerala. Int J Biomed Res. 2015;6(5):331-3.

6. Samiya M, Shagufta R, Samina M, Reyaz AR, Wasiqa K. Ectopic pregnancy: an analysis of 114 cases. JK Practitioner. 2012;17(4):20-3.

7. Shabab U, Hashmi HA. Different pattern of presentation of ectopic pregnancy and its management. J Surg Pak. 2013;18:1.

8. Rashmi A, Gaddagi AP, Chandrasekar. A clinical study on ectopic pregnancy. J Clinic Diag Res. 2012;6(5):867-9.

9. Panchal D, Vaishnav G, Solanki K. Study of management in patient with ectopic pregnancy. National J Integrated Res Med. 2011;2(3):91-4.

10. Stovall TG, Ling FW. Single dose methotrexate: an expanded clinical trial. Am J Obst Gynae. 1993;168:1759-65.

Cite this article as: Murugesan A, Prabhu K, Muthulakshmi M. A retrospective study of ectopic pregnancies in a tertiary care hospital. Int $\mathrm{J}$ Reprod Contracept Obstet Gynecol 2016;5:2537-40. 